\title{
Out of sight, out of mind, but making the best of it: How outstations have worked in the Ngaanyatjarra Lands
}

David Brooks and Vikki Plant

This chapter discusses an exceptionally remote region of the Western Desert in which outstations have played a significant role. Outstations have not, however, necessarily or always been linked with self-determination here in the way suggested by the title of this volume, giving us one matter to disentangle from the start. But another question also immediately follows: was the arrival of self-determination necessarily such a watershed moment, as the premise of this volume's title seems to suggest? That is, was there one basic trajectory that applied throughout remote Australia, within which at a certain point self-determination provided the compelling response? We do not suggest that self-determination did not make a big impact in the Ngaanyatjarra region, as elsewhere, and bring with it many gains, but we do wish to problematise the historical part that it played.

We begin by considering some manifestations of outstation phenomena that came well before the self-determination era and accompanying outstation movement 'proper' of the 1970s. We will sometimes refer to the latter as the 'winds of change' movement, alluding to the national political associations and flavour that it had. 
We identify the first local manifestation of phenomena generically classifiable as outstations to have been the 'summer holiday camps' or 'Christmas camps' that are associated with Warburton Mission history from the 1950s through to 1972. Virtually the whole Aboriginal population of the mission, which was the centre at which most Ngaanyatjarra people settled, would go to stay temporarily at one of several camp areas out from Warburton, remaining for up to three months, while the mission itself went into 'stand-down' mode for the summer. A degree of mission support would be provided, but other than this, the people would live off the country and do whatever they wished. In effect, these were 'intermittent' outstations. They did represent at least partially a 'return to country' and a return to a life less influenced by the mission, but the people would go back in between times, and for stays of much longer duration, to the centralised mission world. Also, of course, such camps did not represent a decentralisation of the population as such, and a winding down of the influence of the mission as a place of colonial congregation, in ways that are associated with the outstation movement proper and with the accompanying notion of self-determination. In fact, during the heyday of the summer camps, the mission was increasing in size and to some extent in influence. The summer camps developed out of, and as a consequence of, the people's increasing involvement with the mission, and in one sense, it could be argued, were a means of facilitating their increasing incorporation into the European world by softening what might otherwise have appeared as too drastic a step to take. But it could equally be argued - and this is much truer to the general Ngaanyatjarra view on the matter - that the people actively chose, for a long time, to become only partially involved in the mission environment, and that the summer camps represented one of the compromises that they negotiated with the mission to retain some autonomy while engaging in a gradual adaptation to a more sedentary, incorporated life. To better appreciate these and other matters pertaining not only to the summer camps but also to the subsequent period of the outstations proper, it is necessary to go back further in time to the beginnings of Ngaanyatjarra interaction with the "whitefella' ${ }^{1}$ world.

1 This is an Aboriginal English term for non-Aboriginal people. 


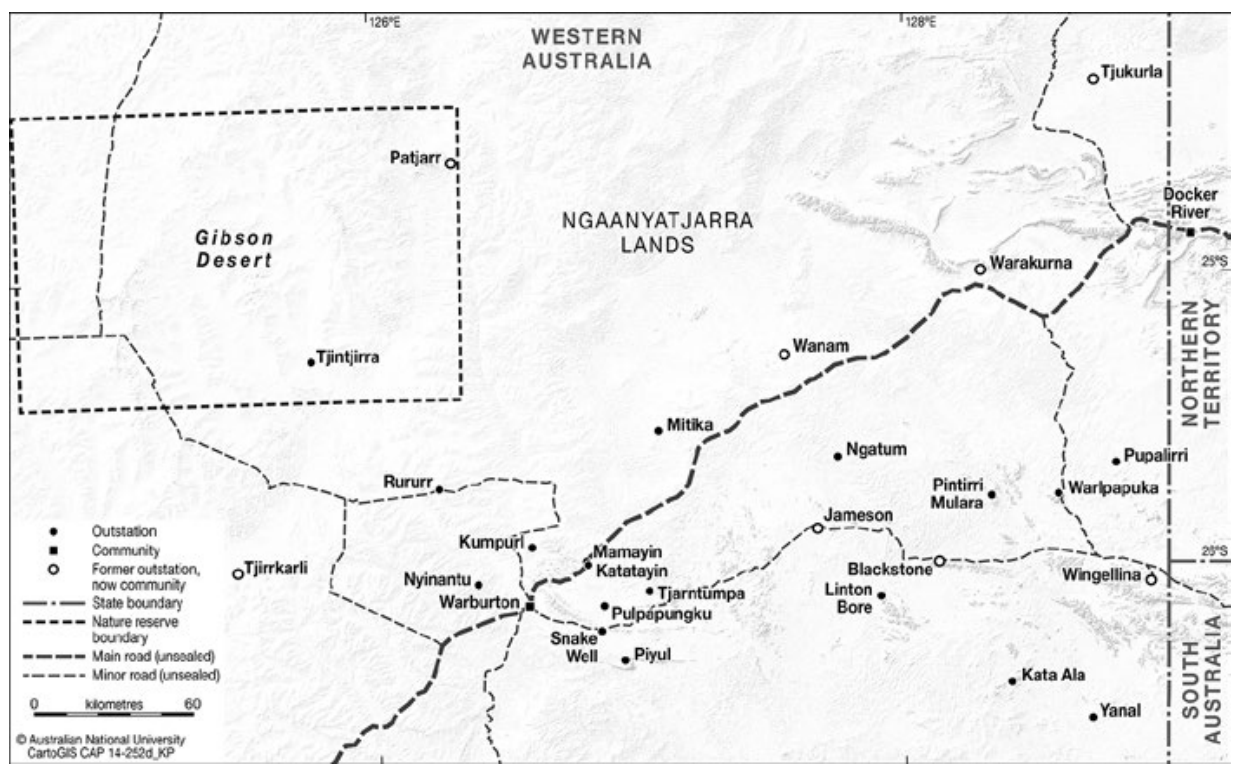

Map 7.1 Ngaanyatjara outstations.

Source: Karina Pelling, CartoGIS, ANU College of Asia and the Pacific

\section{Warburton Mission history}

The Warburton Mission, established in 1934 by the United Aborigines Mission (UAM), was, until its relinquishment of control of the settlement in 1973, by far the biggest factor in the encounter between the Ngaanyatjarra people and the European world. Not only was it the first point of contact, and a very lasting one, for most of the people, but also it has indelibly shaped the history of the region. Because of the area's extreme remoteness and lack of attractions for Europeans, the involvement of, or impact arising from, other external influences has been very limited and may be summarised quickly. The gold rush around Kalgoorlie and Laverton in the 1890s was the first impact, but it was an indirect one, instigating an outward 'drift' of some people from their desert homelands towards those centres - a phenomenon that has continued at a low level right up to the present, though it has been counterbalanced by returns made by many of the people concerned. After the gold rush itself, small parties of prospectors, explorers and 'doggers' came through the area, but their impact was minimal. No significant impacts of a direct kind, other than the mission, arose until the 1950s. In this decade, the WA State Government permitted access by several mining companies to areas around Wingellina and Blackstone in the Central Ranges, while in 1956 the Commonwealth Government built the Giles Weather Station in the Rawlinson Range. A little later, another mining company 
explored in the Jameson area. Vehicular roads appeared for the first time in the Ngaanyatjarra Lands in connection with these initiatives, and the developments affected the area in a number of ways, although the mineral exploration activities were unsuccessful and temporary in nature. Overall, the external impacts other than those associated with the mission could not be considered transformative of the area, although the extent of the impact may be measured by the fact that the first four settlements of the outstation movement proper were sited at Wingellina, Blackstone, Warakurna and Jameson - all places singled out by whitefellas in and through the developments just mentioned.

But while the Warburton Mission was the key whitefella institution in 40 years of Ngaanyatjarra history - and in the founding period when many of the lasting patterns of black/white interaction were created - a crucial fact about the mission from an analytical point of view is that it was essentially a very powerless institution. For virtually the whole time of its presence at Warburton, it teetered on the verge of collapse through lack of finance. Mainly as a result of this precariousness in its position, the missionaries' powers vis-à-vis the Ngaanytatjarra people were in most respects very limited. It is truer to say that the missionaries lived in fear that the people would withdraw from them than that they exercised control over any kind of captive audience. The carrot was necessarily the weapon of choice for them, rather than the stick. Yet in spite of this powerlessness and their frequent ineffectuality, some of themnotably, the founder, Will Wade-achieved a strong rapport with the people through demonstrations of commitment, humility and openness, giving rise to the universally fond regard in which the mission continues to be held. Thus, they were not without influence and even authority; it was just that other factors served to limit their capacities severely.

The tentativeness of the mission was founded mainly on the effects of that same remoteness that discouraged other parties from coming to the region. The significance of this remoteness in so many ways cannot be overstated. Even in the 1950s, it could take three weeks for the mission truck to get back and forth from civilisation as represented by the mining town of Laverton, itself more of an outpost than a centre. But coming on top of the difficulties arising from the remoteness was the consistent and debilitating neglect displayed by the State Government of Western Australia. In part, the Government's disregard probably sheets back, yet again, to how remote and 'out of sight, out of mind' the area was and is, but the Government was also always hostile to the mission and refused to assist it in any way for almost the first 20 years of its existence. ${ }^{2}$

2 It is perhaps worth noting for comparative purposes that unlike their counterparts at Ernabella, the Warburton missionaries had no middle or upper-class links into metropolitan society, and government correspondence shows that as people they were viewed by many bureaucrats almost with contempt, and certainly with none of the respect that someone like Dr Duguid of Ernabella commanded in Adelaide circles. 
The financial survival of the mission, meagrely realised as this was, is a critical matter, in that it points to a marked interdependence that developed between mission and people. A powerful mutuality arose in intentions, desires and strategies, intertwining the very destinies of the respective parties. It is present in the way that the mission responded to its impoverished situation. Apart from the small income from the donations of church supporters, it had few options available, but it managed to find one. Though the subject is rarely mentioned in the missionaries' own records, their survival came to depend on the dingo-scalp trading in which they engaged with Ngaanyatjarra people. The dynamics of this trade are significant. The basic facts were that scalps brought in by the desert people, and repaid with food and clothing items, were used by the missionaries to claim the bounty that governments across several jurisdictions had instituted to lessen the impact of the dingo on the pastoral industry. ${ }^{3}$ In many regions, the collection activity was monopolised by non-Indigenous 'doggers', but not so many of these made their way to the Ngaanyatjarra Lands, which were apparently too remote even for them. Doggers were far more prevalent in the Pitjantjatjara Lands, which were significantly closer to settled areas.

The new activity was taken up almost universally by the Ngaanyatjarra desertdwellers at a very early point in their interaction with the mission. The pattern that developed represented in effect the first form of engagement with the whitefella for most Ngaanyatjarra people and the characteristic one for many years to come.

An important aspect of the dynamic arose from the logical fact that the best way for the desert people to get the most scalps was by spending their time mostly not at the mission but out in the bush, preferably distributed as widely as possible. In other words, the ideal from a dingo collection point of view was that the people should maintain close to their pre-contact way of life and territorial distribution, with one difference: that they would make periodical visits to the mission to hand in their scalps. This was, in fact, basically what happened for the first 20 years or more of the mission's presence. It was a scenario that worked for the mission, at least from the financial point of view, which was the most critical issue for them. And it also worked for the people, who by this means were able to obtain the whitefella foods they quickly came to like, primarily flour and sugar items. Whether or not it was intentional, this situation also meant that the people were able to pace their rate of adaptation to the whitefella world as represented by the mission. It appears that most of them were quite happy to do this, and to remain basically as band-dwellers in

3 There was an agreement with the Government that the mission could return half the value of the scalps to the people in goods, and put the other half towards the running of the mission. 
the bush. To a considerable extent, however, it was not an option for them to move into the mission even had they so desired, as there would generally be no food awaiting them there.

In time, for a range of mutually reinforcing reasons that in general terms were repeated over and over around Australia, the degree of ability, and perhaps inclination, of the Ngaanyatjarra desert bands to maintain their old pattern of territorial organisation and way of life decreased, and they became centred more and more on the mission. If the engagement in dingo-scalp collection represents the first phase in the transition to incorporation into the whitefella world, the second phase was heralded by this increased centring on the mission. This occurred as they became more accustomed to and then burdened by whitefella food, clothing and other possessions, while their previous levels of good health and fitness - essential to living the mobile desert life - declined. Overall, the forces driving longer stays at Warburton multiplied. By the 1960s, the population at the mission was well into the hundreds and rising, with more and more people staying there on a semi-permanent or permanent basis. The dingo-scalp trade was now dying, with an accompanying decline in finance to the mission from this source, while no new source had arisen. Overcrowding and the associated pressures were becoming dire and were to remain so until 1975, which was when the 'winds of change' reached the region, and government funding in a sufficient quantity to make a difference arrived for the first time. This was Commonwealth money for the purpose of establishing major outstations at four well-spaced sites across the region, in the process changing the entire complexion of the Ngaanyatjarra Lands.

\section{Summer holiday camps}

Well before this time, however - in fact, right back in the early 1950sa solution to the gradual centralisation at Warburton emerged that again worked for everybody, as had the dingo-scalping symbiosis in its time. This was the phenomenon of the summer holiday camp alluded to above. An early precursor of the camps occurred in the dingo-scalp days as some groups whose country was far out from the mission, instead of returning entirely to the desert ways when their stint at the mission was over, began basing themselves closer in, and taking some of the desired whitefella foods with them back out bush. The closer proximity meant that in turn it became feasible for the mission to service them as they started to need this. As more groups went down this track, however, such servicing became increasingly onerous for the mission. Hence further compromises were made, resulting in a smaller number of serviced locations, each of which would be occupied by two or more groupings that would previously have lived separately. Thus, the very composition of the groups as 
bands was changing even as the reasons for them to remain constituted as bands were evaporating. The distinction between living in one way (at the mission) or living in another (in the bush) was collapsing. It was no longer, or not only, a matter of the mission temporarily accommodating groups that were essentially still desert-dwellers, but about dealing with the situation of people who had effectively become sedentarised at the mission, or one could say incorporated within a world constituted by the state. But even as this was all happening, and groups were descending in numbers on Warburton or close by, there arose a push from the people themselves to find a way back, if in modified form, to where they had come from. For the mission's part, with the numbers and the pressure rising, there was a complementary imperative to alleviate its own increasingly unsustainable burden in whatever way it could. Getting some of the people out from the immediate mission area at least for some part of the year helped, as long as the servicing costs could be contained. Thus emerged the summer camps, at locations that soon came down to about three in total, sited along the better roads and about $30 \mathrm{~km}$ from the mission, and eventually equipped with bores and water tanks. The orientation of the campsites from the mission was determined in a rough manner by the country of origin of the occupants. Thus, two were located to the north and one or sometimes two to the east, these being the directions from which most of the mission residents came. The most well used of these were Mamayin, Katatayin and Snake Well. These can still be seen in varying states of repair today, and are remembered as the outstations of the mission time.

In summary, there are two features to emphasise about the mission time scenario. One is the interwoven character of the story, in terms of the actions and orientations of those involved. This interweaving was not present in the same way in the dynamics of the following period, that of the outstation movement proper. The second feature concerns the way in which this very interwoven character of relations starts to disintegrate towards the end. Once the dingo scalping was over, the people were left with little of a concrete nature that could allow them to either maintain some independence or negotiate an arrangement with the representatives of the state, as they had effectively done to this point. The interactions and the reasons behind them become more clouded and complex to decipher, though the inexorable decline in autonomy is apparent enough. It was not necessarily a matter of the state wanting to control themalthough in certain respects this was undoubtedly a factor-but the situation arose ultimately as the consequence of the loss by a people of the ability to provide for themselves. The Ngaanyatjarras delayed this loss, but could not stave it off forever. 


\section{Outstations}

In the case of the outstations of both the mission and the self-determination eras, association with a particular country was a major priority for the people. In the mission period, there was a countervailing pressure to centralise. In the case of the 'winds of change' movement, one of the major points was to do away with this kind of pressure and free people up to live in their country and away from the centres established by white agencies; but in fact, of course, wherever there are budgetary limitations a pressure to centralise will exist, and such limitations are never absent for long.

The outstation enterprises of either period could minimally be described as activities involving a person or group that wants to be able to live, if not fulltime at least part-time, at or near a place remembered from or associated with the past. In explanation of their motives - and this material relates to more recent times, because we have no record of the contemporary ideas of the summer camp participants - many have described themselves as having been preoccupied by thoughts of the country concerned. This preoccupation is often expressed in English as 'worrying for' a place, although interestingly the Ngaanyatjarra term is simply kulilpayi, which is a broadly used term meaning listening or understanding. The connotation of a thought nagging away at someone, which is captured in the English term 'worrying for', is not necessarily present in the Ngaanyatjarra term. In some cases, the motivation may be more specifically explained as a matter of a desire or need to fulfil obligations associated with a place, obligations that are likely to involve the protection of or care for tjukurrpa (Dreaming) sites, or other considerations based in desert culture. There are many other possibilities here, including cases where a person is seeking recognition for or wishes to gain possession of a place for the political advantage that this could bring. Whatever the case, the proponent will always have significant prior associations. It should be noted though that while the summer camp locations were always oriented to places whose associations were located in the pre-contact past, the locational choices made in the later movement were often oriented to an 'intermediate' past, one lived out during the decades of the preceding mission era.

The 'winds of change' might have been blowing for some years in parts of Australia, but they did not reach the Ngaanyatjarra backwater until 1975. Meanwhile, the decline in autonomy that began with the end of the dingo-scalp trade and progressed slowly through the remainder of the mission period had long since reached its nadir. By the early 1970s, the people were all in Warburton and even the summer camps had been discontinued. The missionaries had bowed out, limiting their activities to what was now called 'Christian fellowship', and to linguistic work. There were no successors to the centralising and leadership role 
that they had once played. Government - that is, State Government - was slow to arrive, and when it did come its manifestations were confused, and divided, while the money available to assist the people seemed no more plentiful than ever. It seems fair to describe these as years of hiatus in Warburton. In 1975, missionary Wilf Douglas, now visiting as an observer, wrote:

As well as the advisor supplied by W. D. Scott and Co, the Federal Government was represented by a Department of Aboriginal Affairs Advisor. The State was represented by officers from Community Welfare, Medical Department, Community Health, State Housing Commission, Education Department, Kindergarten Union, and now also the Police Department. Then the Australian Inland Mission is represented in the hospital, there are the UAM linguists and one other missionary, also represented are C. P. Bird and Co, the Cooper and Oxley Construction Company, plus the Aboriginal Lands Trust, the Aboriginal Affairs Coordinating Committee, the National Aboriginal Consultative Council, and the Warburton Community Council. (See Douglas 1978: 118-9)

In the same paper, Douglas refers to a visit by a Commonwealth politician to Warburton in 1972 during which he promised houses within six months. Two years later, when another Commonwealth politician visited, the people 'pointed to a disarray of used car bodies and stated, "Your predecessor promised us houses - do you see those old bombs? They are our houses now."' At the same time, before the eyes of the senator there was a large settlement of airconditioned houses that had been built for the departmental staff and advisers.

This was written in 1975, well down the track in terms of the adoption of the new polices of self-determination and support for outstations introduced by the Whitlam Government. Yet there is no mention whatsoever of outstations in Douglas's report.

As it happened though, and perhaps there was a connection, it was to be in that same year that funding did arrive for the implementation of the outstation movement, and the four major outstations alluded to above were established. ${ }^{4}$

It should be mentioned that these four initial outstations cannot be considered as having begun life uniformly as outward movements from Warburton, though they did ultimately come to be seen as dispersed around that site as a centre of sorts. The difference is most notable in the case of Wingellina, which was initially settled by a group that had been living for many years at Amata in

\footnotetext{
4 There was one development that at a crucial time functioned as a pressure-release for Warburton, and this was the Docker River settlement. Many Warburton people went there for stints of two or three years or more after 1968 and especially after 1970 to share in the greater income-related money that circulated there. Many of these people were originally from the Rawlinson Range or country to the north of there, so that when they left Docker River, rather than returning to Warburton they moved on to Warakurna, especially after that community received its outstation funding in 1975.
} 
South Australia. Many of the Blackstone settlers also had a recent background in SA centres, though there were also many who arrived there from Warburton, and the impetus came from the latter place. Jameson and Warakurna were more clearly outshoots from Warburton. Overall, it is definitely Warburton that we are looking at in terms of the role played by the 1970s outstation movement in the departure of a sizeable proportion of a centralised population and the concomitant release of prevailing pressures. Internal conflict associated with the prolonged co-presence of large numbers had been brewing for years at Warburton, but by now it had reached the point where the physical and verbal threats and abuse were sometimes so extreme that they are still remembered today, 40 years later.

The four new settlements, when they did come, were modest affairs at first. John Tregenza, who accompanied the people from Amata to take the first community service officer position at Wingellina in 1975, described how he went to Perth to report for his job and brought out a truck, generator and caravan. They had one water tank, and two power cords running off the generator - one to John's family's caravan and one to the store. Tregenza was one of the new breed of 'believers' of the winds of change era, of which there have been many on the Pitjantjatjara Lands, but fewer on the Ngaanyatjarra side. ${ }^{5}$ The big difference in political terms between the new settlements and those of previous eras was that governance (not called that at the time) was by community councils of Aboriginal members, directly funded by the Department of Aboriginal Affairs (DAA). This arrangement was intended to provide for 'self-determination' of local Aboriginal groups vis-à-vis the staff around them, who were now in their employ, and to cut out many other interests at various levels, such as accountancy firms, which had been exerting de facto control in often complex and opaque arrangements. The citation from Douglas above indicates that these intentions, which were to apply to a centre like Warburton as much as to outstations, were not always or easily realised.

While the actual benefits of the new era were slow to arrive, some Ngaanyatjarra people had come to know early on about the new ideas and the developments that were happening in other places. Some Ngaanyatjarra men, notably Tommy Simms and Fred Forbes, identified from an early point with the self-determination and land rights ideology and imagery, and later were in the thick of trips to Parliament House in Canberra, in company with Pitjantjatjara Council lawyers and anthropologists and the like. The delay in fulfilment of the promises that sounded so alluring added to the many frustrations and pressures of the time.

5 This new breed tended to wear red headbands, have strong commitments to land rights and selfdetermination, speak the desert language and have close domestic associations with the desert people. 
Apart from the matter of getting out from Warburton, what were the circumstances and atmosphere surrounding the actual mobilisation of individuals and outstation groups and the choice of the particular four sites chosen? Some of it involved the hopes and dreams given shape in the winds of change ideology, as illustrated in the following account by Jim Downing, a Presbyterian minister and later activist. Downing refers to the Woodward Commission into land rights. One of its meetings with Aboriginal people in Alice Springs was attended by Fred Forbes, who lived at Warburton, though his country of identification was Blackstone. The ideas of land rights were strongly linked in many minds with those of self-determination and outstation development, and such meetings might be attended by people, like Fred, who would not be part of the specific case of the NT legislative push. Downing says:

Those discussions greatly stimulated the hopes of ... Fred Forbes, a middleage man of considerable authority [who] told me 'The men asked me to go to that meeting in Alice Springs to speak for them.' He spoke so well in his own language, Ngaatjatjarra, that I overheard a Queen's Counsel on the Commission say to a colleague, 'I don't know what he is saying, but what wouldn't you give for that eloquence and that kind of presence in court?'

Fred said of that meeting, 'I told them, "It is Aboriginal men's land and rocks and hills, and White men came later." So I took a map back to Warburton and showed them.' (Downing 1988: 61)

Downing goes on to relate how Fred told him how he got assistance to fill in a form to apply for incorporation, and a few weeks later was told he could go out and sit in his country. It is common local history that he and his group lived under bough shades at a site named Warutjarra, a few kilometres from the Blackstone site, for several months, with stores being trucked out to them from Warburton while they waited for the bore-drillers and builders to arrive.

Downing concludes: 'It is my firm belief that the quiet dynamic enthusiasm of Fred Forbes, his response to the Woodward Commission and his full reporting to the people ... [at Warburton] stimulated the establishment of ... [Jameson] and Warakurna also' (1988: 61).

A somewhat more humble perspective comes from Herbert Howell, a missionary who at the time had been in the Ngaanyatjarra Lands for 10 years and who not only witnessed events first hand, but also lived close to the people of Warakurna both before and after the establishment of the community in 1975. After describing how these people had found it very difficult to stay in the Warakurna locality since the mid-1950s because of the attitude of the Giles Weather Station administration, he relates how: 
In 1973-74 the Government began to encourage Aboriginal groups to return to their original homelands, providing funds to sink bores and erect basic facilities. There was great rejoicing among those from the Rawlinson Range. They happily returned to camp on the doorstep of the Weather Station. (Howell n.d.)

A point noted earlier was that the four initial outstation sites were 'well spaced'. This in itself was important and must certainly have been a factor in the decisions. There would have been pressure from government and others to ensure that the initiative brought about a fair and even dispersal of the population across the available land. But the map shows that the four sites were not by any means distributed equidistantly across the surface area. They are in fact located close to the main ranges of hills in the Ngaanyatjarra Lands, which are in broad terms the most fertile areas. It could be correctly assumed that these were places where the classical population was particularly concentrated, but other factors were at play as well. All the sites were places where whitefella activities had produced concentrations of Ngaanyatjarra population in the not too distant past. Thus, to some extent, the choice of locations was not a manifestation purely of the 'voice of the people', but was a more straightforward and practical matter of the existence of some significant infrastructure - bores, roads and the likeassociated with the mining industry and the weather station.

\section{The location of outstations}

It can be taken for granted that every outstation that is built has a group that is pushing for it, and that the desire for outstations exceeds the number that can be funded. Whatever the politics was and whoever the players were, when the situation was being looked at in the lead-up to the 1975 deployment of funds to the Ngaanyatjarra region, Wingellina and Warakurna did virtually pick themselves, down to the actual location, within a range of a few kilometres. In addition to possessing the practical assets that have been mentioned, both had large numbers of potential residents who were keen to move in. They had strong Ngaanyatjarra proponents. And, though this is not a subject that we have so far flagged in this chapter, there were major sites of cultural significance very close by. The same is essentially true of Blackstone, though there was less prior specification here about the location of the community. It could probably have been placed at a number of spots within a radius of 30 or $40 \mathrm{~km}$. Jameson had to win out against other competitors.

There were to be no more major outstation developments in the Ngaanyatjarra Lands until the late 1980s, when Tjukurla, Patjarr, Tjirrkarli and Wanarn were established under somewhat different arrangements, with heavy support from the Ngaanyatjarra Council, a non-governmental body that had emerged 
more recently. These four, together with the initial four, became known as 'communities' and all are still running today. But in the aftermath of 1975 there were many individuals and groups whose aspirations were not catered for by the framework of the first four. In following years, small amounts of funds were made available for the establishment of mini outstations at about 20 places. Each of these survived for varying periods but none has stood the test of time.

\section{Conclusion}

We have concentrated here on providing some underlying insights about the outstation movement by contextualising it within the broad narrative of Ngaanyatjarra interaction with the outside world and its local representatives. We have seen how at first the engagement had a collaborative character, which for three decades or so worked in a way that could be judged successful for the Ngaanyatjarra, at least in terms of issues of maintaining autonomy, until that particular dynamic died away, and the people were left effectively stranded at Warburton and cut off from the land that had continued to sustain them until very recently. And we have seen how the hiatus that set in at Warburton was broken when the outstation funding arrived-funding that came out of the new mindset of 1970s Australia - allowing a new direction to be pursued that again involved the occupation and the use, albeit in a somewhat different way, of the land. What of the new interactional field that developed along with the outstations of 1975 and later? While there was never quite the same sort of collaborative character, the same interweaving that had characterised the mission time, the influence of the early experience of those kinds of relations persisted. At no time have the Ngaanyatjarra been inclined to espouse antiwhite sentiments, or to be preoccupied with demanding control of all the affairs of the region. It seems fair to say that they did not 'need' many of the ingredients of self-determination as a policy, but they had certainly come by the 1970s - or earlier - to need government support. The support was needed both to create outstations away from Warburton and to improve conditions at Warburton itself. But given the conditions of the time, support was going to come as part of the self-determination package, whether or not the package as a whole was wanted. And it is in the nature of the notion of self-determination that a distance between white and black will exist - a distance conceptualised by proponents not as a negative but precisely as a positive. It was seen that a space is necessary, for restorative and maybe developmental purposes: the whitefellas needed to 'back off'. But for a group whose history did not really contain a sense of oppression or domination, the distant stance of the new crop of whitefellas that came with the new funding has often been perplexing for the Ngaanytjarra. Bearing in mind that the more recent staff who have come 
their way have not tended to be in the activist mode, but rather politically and personally conservative, the Ngaanyatjarra have not been quite sure why they have come, other than to get a paid job. They have not got to know most of these staff well as people, but partly because the Ngaanyatjarra attitude to whites is mostly benign, the staff tend to stay on for long periods, and everybody gets on amiably enough. The Ngaanyatjarra attitude may be summed up as, 'You do your job helping us, and we'll live our lives'. All well and good. The missing elements, though, have been in the area of leadership and in the development of an increased-and necessary-engagement with the outside world. The Ngaanyatjarra relationship with this outside world, via the missionaries, began felicitously, but against this background, and to some extent because of it, what came next - self-determination - was not the ideal progression. For Aboriginal groups that had something to fight back against it probably allowed for the development of leadership and a sense of forward movement, but for the Ngaanyatjarra it created not so much a space as a vacuum.

Interestingly, the Ngaanyatjarra have done quite well in some respects. The stability associated with their working accommodation with their staff has resulted in them having come to own a number of valuable assets that have provided some services and income independently of government. These assets have included a set of elaborate and effective goods, services and transport provision companies, as well as businesses in Alice Springs. By these means, the region is at the time of writing one of the few places that has been able to retain self-determination as a working reality within its communities, some seven years after the Commonwealth moved away from policies of this kind to more authoritarian, centralised approaches.

\section{References}

Douglas, W. 1978. Evolution of a rampage of destruction at Warburton Ranges. In M. C. Howard (ed.), Whitefella Business: Aborigines in Australian Politics. Philadelphia: Institute for the Study of Human Issues, pp. 105-24.

Downing, J. 1988. Ngurra Walytja: Country of My Spirit. Darwin: North Australia Research Unit.

Howell, H. n.d. Why move to Warakurna? Unpublished report. 
This text is taken from Experiments in self-determination: Histories of the outstation movement in Australia, edited by Nicolas Peterson and Fred Myers, published 2016 by ANU Press, The Australian National University, Canberra, Australia. 